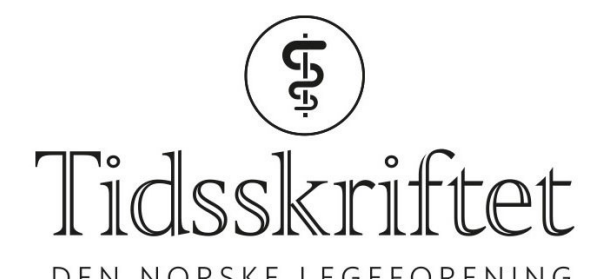

DEN NORSKE LEGEFORENING

\title{
Store svakheter i kreftstudier med nye legemidler
}

FRA ANDRE TIDSSKRIFTER

KETIL SLAGSTAD

Universitetet i Oslo

Halvparten av studiene for nye, godkjente legemidler mot kreft hadde høy risiko for systematiske skjevheter.

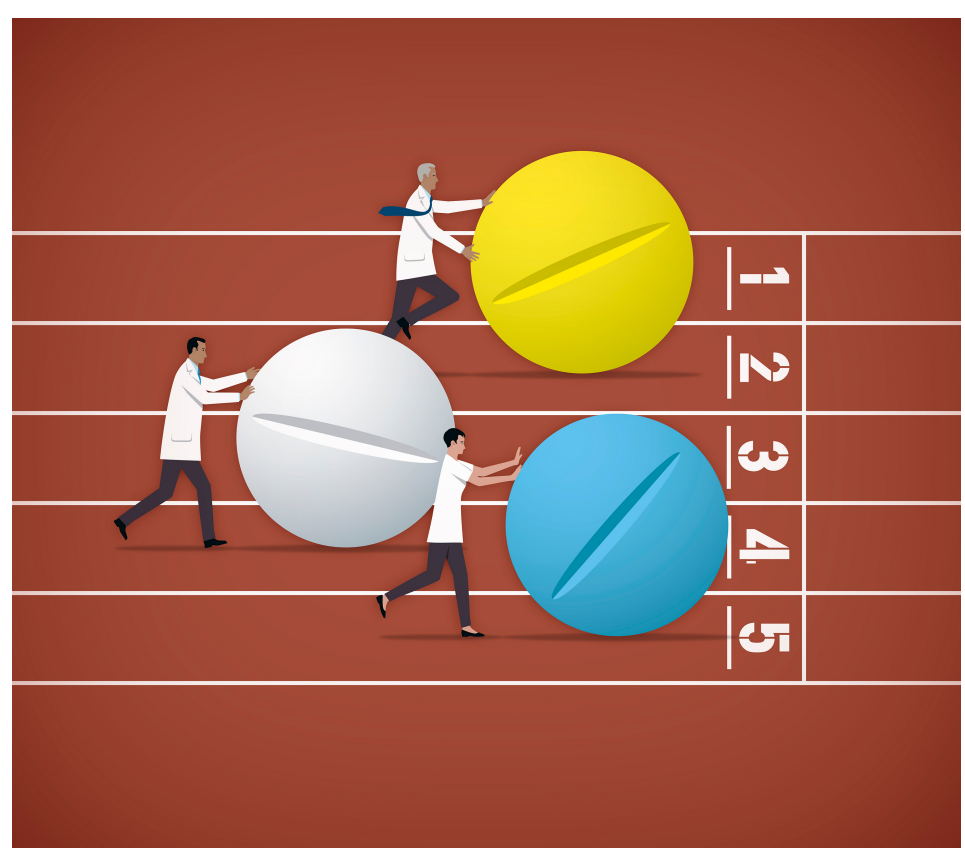

Illustrasjon: Ikon Images / NTB Scanpix

Forfatterne av en ny artikkel publisert i BMJ analyserte dokumenter fra de europeiske legemiddelmyndighetene, registre over registrerte legemiddelfors $ø$, publiserte artikler og appendiks for nye kreftlegemidler godkjent i perioden 2014-16 (1). I perioden ble 32 nye kreftlegemidler godkjent, bl.a. midler mot myelomatose, melanom og lungekreft. Godkjenningene var basert på 54 studier, hvorav tre firedeler var randomiserte, kontrollerte studier. Resten var enten ikke-randomiserte eller enkeltarmsstudier.

Kun en firedel av studiene hadde totaloverlevelse som primærendepunkt, mens progresjonsfri overlevelse var primærendepunkt i halvparten. Halvparten av studiene hadde høy risiko for skjevheter (bias) basert på Cochranes instrument for systematiske skjevheter. Hovedproblemene med studiene var knyttet til manglende rapportering av behandlingsutfall og hvordan utfall ble målt. 
Forfatterne av en kommenterende lederartikkel etterlyser at terskelen for godkjenning av nye kreftlegemidler bør heves (2). De påpeker at ettersom enkeltarmsstudier har fått $\emptyset \mathrm{kt}$ betydning i godkjenningen av nye legemidler, må man kvalitetssikre at legemidlene faktisk fører til bedre behandling.

\section{LITTERATUR:}

1. Naci H, Davis C, Savović J et al. Design characteristics, risk of bias, and reporting of randomised controlled trials supporting approvals of cancer drugs by European Medicines Agency, 2014-16: cross sectional analysis. BMJ 2019; 366: 15221. [PubMed][CrossRef]

2. Mintzes B, Vitry A. Flawed evidence underpins approval of new cancer drugs. BMJ 2019;366: 15399 . [CrossRef]

Publisert: 14. november 2019. Tidsskr Nor Legeforen. DOI: 10.4045/tidsskr.19.0681

(C) Tidsskrift for Den norske legeforening 2020. Lastet ned fra tidsskriftet.no 